\title{
BLACK CAPITALISM: THE PATH TO BLACK LIBERATION?
}

\section{Introduction}

Back in 1960 the demand at Greensboro, North Carolina, was for a twenty cent hamburger at a downtown white-owned lunch counter. Since then, freedom rides, sit-ins, marches for jobs, income and decent housing, and finally urban riots have become vehicles for black expression against racism and for a fair share of American affluence. The response of the white corporate sector to such anguished calls for change has been, in general, indifference, if not open hostility. Only when the smoke from ghetto uprisings could be seen in their suburbs did corporate management begin to realize that the problems in the ghetto were potentially their problems as well.

In the absence of business support, the federal government responded to the clamor for meaningful social change with a portfolio of inadequately funded reforms. Beginning with the Manpower Development and Training Act (MDTA) in 1962, the government concentrated its efforts on injecting job skilis into the poor so as to transform them into useful inputs for the expanding business sector. The Johnson administration later introduced an assortment of "Great Society" programs dealing with health, education, housing, sanitation, and legal aid in an attempt to broaden the attack on poverty. Typically, these programs were designed to outfit "misfits" with the qualifications necessary for effective job competition in a newly evolving supertechnological labor market.

Increasingly, it has become clear, however, that under the continued stress of Vietnam spending, the "Great Society" wax on poverty has been reduced to a skirmish, one that we are hardly winning. And so it is, that while some progress has no doubt been made through the Job Corps, the Neighborhood Youth Corps, and programs with the soaring aspirations of Upward Bound and Vista, the fact remains that the ghetto survives rooted to the inner city soil very much as it was before the days of the New Frontier. At one time or another, some minority of American minorities may have been aided by these inadequate schemes, but the economist's logic cannot be denied: the marginal benefits from poverty programs have been purchased at high opportunity cost. Transferring the meager war on

* Research Associate, Institute of Labor and Industrial Relations, The University of Michigan. 
poverty program funds directly to the poor in terms of income supplements possibly would have yielded a higher benefit/cost ratio in welfare terms.

Nevertheless, a new optimism is growing in some quarters, for out of the rubble of incinerated ghettos has grown a fresh perspective for liberating black America. The new plan, "black economic self-determination," entails black ownership, operation, and control of business enterprise. Ironically, this scheme developed by black militants appears to have caught the fancy of government officials on both sides of the aisle as well as won the enthusiastic support of a previously disinterested corporate "elite." Under the rubric of "black capitalism" - a term coined by the mass media -- the illusion has been generated that such diverse personages as Roy Innis of CORE and Arjay Miller of Ford share the same political-economic perspective. The fact behind the lllusion, however, is that "black economic self-determination" and "black capitalism." are potentially very different games played under vastly different rules. Indeed, one set of rules may portend a viable innercity political movement with some new jobs within an internally controlled inner city economic base while the other may lead to a few more jobs for the black community, but inevitably at the expense of greater inner city subservience to the white economic structure.

\section{The Ghetto Economy}

According to recent estimates, blacks constitute over $11 \%$ of the population, yet own or operate less than $1 \%$ of the nation's five million private businesses. 1 Fewer than $31 / 2 \%$ of the non-white labor force are managers, officials, or proprietors, while $14.2 \%$ of white employment is found in such occupations. And while one in forty whites is a proprietor of some sort, only one in a thousand Negroes is so situated. The distribution of business enterprises is, indeed, even more dismal than these statistics imply, for an overwhelming proportion of Negro-owned business is extremely small-scale and marginal, lying at the periphery of the American economic structure. It should come as no surprise, then, that the black customer, even in his own neighborhood, inevitably faces a white man when he buys his furniture, his clothing, or his vegetables.

This condition has become, of course, increasingly intolerable within the black community. Witness that in Watts, in Detroit, in Newark, and in numerous other black communities, the first molotov cocktail targets were white-owned storefronts, neon-lit symbols of a "honky"-dominated culture and equally important, symbols of an entrenched lily-white. 
economy. Even if the black customer got what he paid for in the ghetto shop, the condition would remain intolerable, for the seller-buyer relationship inside the ghetto remains a white-black relationship with all its implicit status connotations. Yet, even here it is clear from studies by Caplovitz and others that the inner city poor pay more and get less than the suburban rich.2 In this light, the ghetto black suffers from living in a "company town" with a "company store" and rarely accumulates enough to escape. Thus, with the routes to the outside world blocked by segregated housing, low incomes, and often inadequate public transportation, black leadership has turned inward to its own community to find the means of escape. The evolving solution contains a detour within the ghetto.

The call has gone out to expropriate the company store and develop it to meet the needs of the community, and not the pocketbooks of absentee landlords and shopowners. The initial demand calls for blacks to take over or buy out ghet to shops and then not only manage them, but reap the profits that might accrue from such enterprise. More far-reaching, however, is the expressed desire to expand the ghetto's economic base. For it is clear that while the expropriation of retail shops, laundries, and small scale customer service industries will place black faces behind the counters, the misery of low incomes and constant subservience can never be overcome by small-scale superficial means. Development of a production as well as a distribution sector is necessary to generate a viable economy.

Such a development, however, necessarily requires tremendous capital and expertise, two "commodities" which are not native to the inner city and must be imported from White America. For this reason, many black communities are turning to the federal government and large-scale white enterprise for aid. The response from Washington and especially from the top men of the corporate sector, as we have indicated, has been more than mildly enthusiastic.

\section{The Need for Economic Development}

The real problem in the inner cities of America is not white faces behind drugstore counters, a phenomenon only little more than skin deep. 3 Rather the root problem is the total lack of income generating production, the obvious hallmark of a poor community. For all practical purposes the inner city is a devastated region, stifled for decades by a colonial rule which systematically, if not with malevolent intent, deprived its inhabitants of the physical and human capital needed for 
development. Denied the educational resources and the physical infrastructure necessary to develop technical skills and provide an efficient means of production, while at the same time denied access to the corporate sector through discriminatory practices in housing, in the schools, on the job, and in the capital market, the ghetto has been forced to rely upon its one remaining resource: cheap labor. This it exports on demand at a going rate of $\$ 1.60$ an hour or less. During periods of extremely high national aggregate demand, all but $10 \%$ of such supply is bought; during periods of recession, as much as $40 \%$ is left to rot away. The ghetto is thus forced to survive on poverty wages, welfare payments, and anything it can beg, borrow, or steal.

Such an economy, lacking its own means of production and means of distribution, behaves as a sieve. Income injected into the ghetto economy quickly dissipates into outlying suburbs and outside investment. In economic terms, the inner city has a very small multiplier, approaching the value of one. Instead of remaining in the ghetto, passing from grocer to baker to candlestick-maker in return for services or goods supplied, the income dollar brought into the black community in the morning, through a small payroll or welfare check, gets spent that afternoon in a white-owned ghet to store, and leaves in the evening for the suburbs and beyond. Such an income cycle reduces considerably the real income of the community and, what is worse, prevents the accumulation of any meaningful savings which could be turned to investment. The lack of indigenous black-owned enterprise thus accounts in part for the continuing leakages of capital from the ghetto.

Indeed, the cycle described here need not necessarily result in a depleted region. If the multiplier of an area fails to rise much above one, but the region is productive, exporting valuable goods and services to the outside world, affluence is assured. This is the case of the white suburb. But, of course, as we have indicated, the productive capacity of the inner city lies undeveloped, exporting services lightly valued by the corporate established market.

To reverse this condition would require the development of black-owned distribution centers in the form of wholesale and retail outlets, the supply of consumer services, and most importantly, the development of a black-owned and operated production sector, capable of developing and manufacturing goods for sale both internally and for export. In this manner, injections of income into the inner city are greatly expanded and the income multiplier is enhanced. While under present circumstances, a great part of the gain from welfare checks accrues to the white middle class, a developed inner city with a production and distribution matrix would be in a position to 

When the Company was started, we did not have any business; but we were certain that we could do more for Watts by putting a plant there than by trying to absorb 500 Watts residents into our regular work force at plants which were 20 and 30 miles away in a city which has inadequate public transportation.

After considerable effort, we obtained a contract for the construction of large hospital tents for the military services. We invested a total of $\$ 1.3$ million in the project. More recently we expanded our product lines to wood working and metal work. Today, Watts Manufacturing Company is a growing concern.

Our company's experience leads me to conclude that in order to establish meaningful business and industry in urban poverty areas, private enterprise must go a bit beyond conventional methods. Flexibility, I think, is the name of the game we must play to be really successful in the inner city today.

While Aerojet's philanthropy created several hundred new jobs in a riot-torn city thereby providing some marginal imorovement in a post-marginal condition, it has done little to ceallign the relationship of the black community to the white jower structure. For the control of the Watts subsidiary does lot emanate from the ghetto; rather the "black" company renains the child of Aerojet and it is to the father firm that NMC, Inc. pays deference, and in the long-run, possibly profits.

Beyond direct corporate intervention in the ghetto are zoncerted efforts to develop black corporations from within the inner city. The most famous and successful of these efforts remains the Opportunities Industrialization Center prorram pioneered by the Rev. Leon H. Sullivan of Philadelphia. In a recent interview, $\mathrm{Dr}$. Sullivan related how he came to establish the OIC and explained its progress.5

One Saturday night when I was thinking about this whole problem, I read about Jesus feeding 5,000 people with bread and fishes a little boy had given Him. The miracle, you see, was in the giving. So I decided that in my congregation we could share our resources and create a financial base on which to build housing and, ultimately, business enterprises. 
Beginning with a quarter million dollars raised from his church, Sullivan invested in a million dollar apartment complex. Later "Progress Plaza," the largest black-owned shopping center in the world was established with 16 privately-owned shops on $41 / 2$ acres. Not content, Sullivan's acquired business sense directed him into the aerospace industry where he created Progress Aerospace Enterprises with management borrowed from the General Electric Corporation and a G.E. subcontract for $\$ 2.5$ million of component production for the U.S. moon mission. In addition, Sullivan's Zion Investment Corporation has established the Progress Garment Manufacturing Company in Philadelphia which employs seventy-five workers. Management responsibility of the Investment Corporation rests in a Board of Directors selected by its 3,500 shareholders. The waiting list for stock ownership is in excess of 2,000 families. Philadelphia has over half a million Negroes.

The Opportunities Industrialization Center program has now spread to over 70 cities and $\$ 5$ million has been raised from the private sector to initiate local projects. Even Puerto Rico, Kenya, Senegal and Nigeria are experimenting with the OIC training program, a program aimed at creating skills for use in private enterprise both in and outside the ghetto. In the United States, the OIC National Industrial Advisory Council, composed of 25 "influential" business leaders has been created by Sullivan to help sell the program to corporate heads who conceivably might give aid to newly developing black business. George Champion, chairman of the board of the Chase Manhattan Bank heads up the Advisory Council.

In appraising the success of his brainchild, Sullivan envisions a bright future for the Negro entrepreneur.

I see the African American becoming a part of American capitalism -- in fact, joining the free-enterprise system worldwide.

For all the years that my brothers and sisters-and $m y$ poor ancestors -- have been a part of America, we have been outside the door of free enterprise, outside the door of capitalism. What I want to see is my black brothers walking through the door of free enterprise, not as "black capitalists" but as blazk men who can join the wholf free-enterprise system and share its benefits.

The Reverend adds,

I think of myself and what I'm doing as "black power" itself -- it is black, it is capitalism, 
it is American. I will never be satisfied until every black adult in America owns a piece of this country individually or mutually, even if it is no more than two square feet of earth or a share of stock.7

How evenly spread the benefits from Sullivan's efforts will be is yet to be seen. Whether capitalism can work for the Negro working-class as well as the bourgeousie remains a moot point. Nevertheless, it appears evident that the OIC program has gained the support of white business and thus the scarce resources of capital and technical expertise seem assured at least in the short-run. But inherent in such a strategy lingers the potential for external domination and control by an "amiable" white power structure. And thus how much of the black community can escape poverty and powerlessness in this way cannot be exactly determined, but surely the rosy beginning need not point ineluctibly to a rosy future.

Yet a fourth strategy is now being developed by a small group of black businessmen, economists, and accountants in Detroit. The Inner City Business Improvement Forum (ICBIF) was established immediately after the 1967 Detroit riot.8 With an inventory showing less than $35 \%$ of the ghetto economic base owned by blacks, and a $\$ 50,000 \mathrm{gift}$ "bribed" from Henry Ford II, ICBIF set out to build a black infrastructure within the inner city to stem the outward flow of black-earned dollars. Over the past eighteen months ICBIF's leadership has evolved a "community concept of comprehensive inner city development" which stresses the need to develop not only retail outlets controlled by the black community, but the absolute necessity of establishing a production sector and black banking system to accumulate internally generated investment funds. Shying away from the paternalistic New Detroit Committee, created even before the 1967 conflagration cooled, ICBIF has turned to individual white investors and increasingly to the government for seed capital. In 1968 "Our" Supermarket was established on Detroit's East side to serve a large part of the surrounding black community. ICBIF provided 10\% of the funds, while a leading city bank and the Small Business Administration picked up the first and second mortgages to supply the rest of the initial capital outlay. Now one-dollar shares are being sold in the community so as to assure that profit from the supermarket goes to the community consumer rather than suburban interests. The board of directors for this supermarket and similar ventures created by ICBIF is chosen by the "block" clubs in the serviced area. This, along with a strict limit'on an individual's stockholdings, ensures democratic control of each enterprise.

ICBIF has also aided traditional black retail businesses, 
supplying them with technical aid and seed capital in some cases. Unlike the major enterprises of ICBIF, these are left in private control along the lines of "corner store" black capitalism. With a combination of community owned and operated supermarkets and privately owned and operated smallscale retail shops, the black community in Detroit is beginning to gain some control over the estimated $\$ 750$ miliion worth of consumer dollars which annually pass over inner city store counters.

ICBIF's comprehensive development scheme has already transcended its humble beginning. Between July and December, $1968, \$ 850,000$ was committed to ICBIF which was used to establish a dozen new black business enterprises ranging from privately controlled clothing stores to a small community controlled iron foundry which supplies parts to the auto industry. On the drawing boards is the First Black National Bank of Detroit, several multimillion dollar shopping centers in the ghetto, and several metal stamping and plastics plants. Along with this program of business development, ICBIF is initiating or already has spawned the following projects:

- A practical training program for black business management

- A computerized accounting center to aid new black businesses in their bookkeeping

- An ICBIF Research Division which studies, among other things, the business profile of the black community and the potential for new enterprise

- A management consultant bureau which makes available lawyers, accountants, production foremen, and engineers to community-owned enterprise

- A black better business bureau where consumers can go to complain about both white and black unfair business practices.

Evidence from ICBIF's first year and a half of operation, Detroit appears to possess the potential for developing a semiautonomous viable inner city economy, one which could provide thousands of jobs and a large number of investment outlets. Aided initially by white business, fearing the chaos of the black ghetto, the plan envisioned by ICBIF foresees a cutting of the umbilical cord to the white community. Free of external manipulation, black control is gained over an independent economic structure which can interact with the white-controlled 
economy from a position of comparative advantage rather than subservience. But whether even this scale of independent black enterprise is sufficient for economic viability, free of white support, is questionable.

To complete a typology of black business strategies, we should add those schemes which are avowedly political and only secondarily economic in nature. The economic development strategy, in essence, is no more than an organizational tool for building an indigenous inner city political base. By investing small amounts of capital, either generated internally or "hustled" from guilt-ridden whites, a nascent community-controlled black economic sector is launched, providing some new employment opportunities, but more importantly, a rallying point for community action. Profits from the enterprise are plowed back into the organization both for further business expansion and for political action. In this manner, the community organization becomes self-sufficient and free from external control. As the economic substructure expands, the political organization matures, benefitting from a well-financed base. Educational and cultural activities can be added to the political thrust of such a movement, thus creating an integrated program of community action.

By now it should be patently clear that each of the strategies outlined above can be evaluated upon two potentially conflicting criteria: first, the speed with which the plan leads to economic development as measured by rising employment, incomes, and capital outlay; and second, whether the scheme possesses a structure and dynamic conducive to economic and political liberation as measured by economic selfsufficiency and political influence. The conflict between the pace of development and self-determination arises from the scarcity of capital and expertise in the ghetto. For the inner city community to develop economically over a short period of time, much capital and talent must be imported from the white community. Inevitably, large-scale importation leads to surrendering some control over the direction of development.

Thus, while one scheme leads rapidly to investment in the ghetto by white business, it almost assuredly fails to promise radical change in the structure of power relations between white and black. On the other hand, development carried on solely by the black community may contribute some political freedom, but at the cost of continued economic stagnation. A conscious decision must then be made by the black community as to which road it chooses to travel, and indeed, how much "liberty" should be surrendered to hasten the development process. For the black community, to have their cake and eat it too will seldom be a permissible choice. 
If black capitalism works, the hope is that the black community will turn inward toward constructing a new set of economic conditions within the inner city rather than turning outward with attempts at reconstructing the conditions of power within the white business community. And while, at present rates, welfare checks designed to dminish dissidence portend an ever expanding social expense and the training of blacks for white corporations appears at best a long-run ameliorative device, black capitalism seems to offer some relief from the immediate chaos, if not from its causes.

Increasingly management also realizes that its own autonomy can be better preserved and long-run profits augmented by reducing the role of the federal government in developing the ghetto. By forging an alliance between black capitalists and themselves and foreclosing a nascent government-black producer coalition, the corporate elite can look forward to lower input costs (in'terms of intermediate goods used by large-scale industry in final goods production) and can spare themselves future competition both for government contracts and in the manufacture of some products. At the same time, such an alliance may appear to corporate management as a defense against "creeping socialism," a specter which still haunts the paranoid. Furthermore, a smaller federal role in poverty programs and a larger corporate role in developing all black subsidiaries in the inner city could lead to a reduced emphasis on legislation aimed at discriminatory policies within the corporate sector. Legislation which now prohibits the federal government from contracting with firms which fail to live up to fair practice codes might be enforced less stringently. Finally, the public relations boost derived from lending a helping hand to the poor as well as the taxsaving from discontinued Great Society programs are viewed as boons to big business.

In understanding the corporate manager's positive attitude toward black ghetto enterprise, one must realize that corporate profits will not be endangered by the introduction of the black capitalism stretegy envisioned by the corporate establishment. The reason is simple: This strategy foresees the black community providing only two generalized products: (1) Retail services to fill the community's need for vegetables, meats, drugstore products, and television repair, etc., and (2) Small-scale manufacture of intermediate goods used in the industrial sector to produce automobiles, washing machines, and computers. In the first case, the corporate sector is left unharmed by black capitalism because the corporate sector sells very little at the retail level and when it does, it usually does not do it in the ghetto. The squeeze here will be on the small-time white shopkeeper; the corner grocer and the local repair shop owner. 
Ghetto manufacturing firms, examples of the second case, will not only fail to deplete corporate profits, but actually will contribute to them. It is for this reason that corporations like Aerojet have spread their "philanthropy" into the ghetto. Excess profits of the largest industrial giants can be invested in the inner city (without fear of retaliation from the government anti-trust division) to establish subsidiaries which provide them with cheap parts and labor hired at less than union scale. With the business perspective of "the poverty problem is a technical problem, "10 corporate enterprise efficiency experts can provide the cost-benefit analyses necessary to ensure profitable gain from inner city firms. For example:

It has been estimated that approximately sixty percent of the value of an American automobile is not produced by the Big Three. Rather this value is due to the literally scores of thousands of parts vendors which manufacture everything from a carburetor screw to a convertib]e top frame and sell them to automobile producers. In other large-scale industry, the value-added by parts suppliers is likely to be as high. Obviously, then, big business is dependent on small-scale enterprise for a large percentage of its profit. If the price of parts is reduced, the profit of the car manufacturer (or the electrical equipment firm or the television set producer, etc.) can be raised with comparative ease.

Somewhere between 75-90\% of the parts vendors for the largest producing corporations are union shops. In many cases, the wage rate paid in such small plants is comparable to that paid in the leading industries. The auto companies, therefore, must pay indirectly the higher union wage of the carburetorscrew machine operator; and this, of course, becomes part of the cost of producing a car. If this wage could be reduced, the cost of the carburetor is cut; and thus the cost of producing an automobile is lower, and GM, Ford, and Chrysler make a higher profit. Multiply this by $60 \%$ of the final value of American automobiles, and the total potential profit gain is no doubt tremendous. Stockholders will be made happy and so will corporate management.

Sidestepping unions in the already organized parts supply industry is a difficult, if not risky practice. Since the $1950^{\prime} \mathrm{s}$, such attempts have been rare by large corporations. But now the opportunity for circumventing union power by means of coalition with the federal government and the black community has emerged. The small plant can pay half the going wage of the unionized vendor operation thereby ensuring a competitive edge over union plants, and yet still pay above the wage scale normally offered low-skilled workers in the ghetto. In this way both the ghetto and the corporation benefit. Such a symbiotic relationship between the corporate 
elite and the community poor at the expense of the unionized workingclass has the potential for evolving as the most exotic in a long line of techniques aimed at curbing union strength. Ford hired blacks to break unions in the twenties and now Ford has a better idea. It, like other modern corporations, has found a new, almost socially acceptable way to do the same thing in the sixties and seventies. Little wonder the AFLCIO has vigorously attacked all black capitalism plans.

Other strategies utilizing black capitalism to produce higher white corporate profit show equal ingenuity. For example, during the short-lived period of $f i v e-y e a r / 50,000$ mile automobile warranties, auto industry executives developed a scheme whereby pre-delivery automobile diagnostic centers would be established in the ghetto, using black labor and white corporate capital and expertise. Such black-owned centers, manned by trained black auto mechanics, would test new cars at company expense before delivery to their prospective buyers. In this way fewer repairs would be required at cost to the auto industry and customer satisfaction would be reinforced. However, before the diagnostic centers were financed, the shorter car warranty was reinstated by the industry. Now the auto firm is no longer responsible for repairing much of its built-in obsolescence, and consequently the industry's savings from pre-delivery diagnosis and adjustment is reduced. The upshot is that the auto executives' enthusiasm for the centers has waned considerably and the project lies on the scrap heap.

Last, but not least, mention must be made again of the profits which can be gleaned from government subsidy programs designed to induce big business participation in inner city development. With such subsidies or tax incentives as specified in the Community Self-Determination Bill, for example, little effort is required on behalf of the corporate structure to create a "ghetto-industrial" complex including cost-plus contracts and the profits they imply. We may not be very far off in concluding that it appears the corporate establishment is more than happy to help the black community -- especially if it gets a little helping itself :

"Black Capital ism" Reconsidered

Business brought into the ghetto by the white corporate establishment may very well add something to the inner city environment. Some new jobs will be created, the average wage in the core city may rise a bit, and a few enterprising 
But what is equaliy true is that no black capitalism scheme which relies on the white establishment for sustenance will lead to a form of inner city economic development which in turn can lead to black socio-political liberation. To put it plainly, it is not in the interest of big business to develop a viable black economic sector, competitive in the newly evolving growth industries. At best the black community will vie with the blue collar union sector for a share of the intermediate goods market.

But if corporate intervention in the inner city will not create a viable economy, can independent private black capitalism, unaided, but also unemcumbered by the mixed blessing of corporate involvement, lead the black community to freedom? The answer is probably no. Independent private black enterprise cannot serve as the catalyst for economic development and political power.

It is a sad fact that private small-scale enterprise pays extremely low wages, reaps little profit for its owner, and consequently contributes little to economic development per se. While black retail capitalism will boost the inner city multiplier by some small amount, the additional income thus generated will fail to raise a significant number from poverty. Consider, for instance, the average hourly wage rates paid in retail trade across the nation in the mid-1960's:11

$\begin{array}{ll}\text { Limited price variety stores } & \$ 1.31 \\ \text { Eating and drinking places } & 1.14 \\ \text { Drug and proprietory stores } & 1.56 \\ \text { Gasoline service stations } & 1.52 \\ \text { Apparel and accessory stores } & 1.70 \\ \text { Retail food stores } & 1.91\end{array}$

These were average rates; the inner city wage levels helped to keep them this low. In addition statistics on low-wage industry profits show that there is little room to raise these wage rates much beyond such low levels.12 All of this is due to the high degree of business competition in the retail field, which subjects the small-scale firm to a profit and wage squeeze. Add to this the additional costs which small-scale business in the inner city must bear because of higher insurance costs, uninsured losses due to crime, and the higher cost of inner city transportation, and the picture of low wages and low profits comes sharply into focus. Hence, while the sight of black faces behind ghetto drugstore counters may be comforting psychologically, it is not economically.

A small private production sector will also fail to add much viability to the inner city economy. In the first place it is highly unlikely that individuals from the black community 
will have the ability to raise sufficient capital, independent of white business and government, to initiate enterprise especially in the fastest growing sectors of the economy: electronics, computers, automation equipment design, etc. To be successful in these industries requires enough capital to keep pace with rapid technological change. In addition the efficient size of manufacturing firms is usually beyond the capacity of ghetto residents with their present inadequate resources. Finally, even if the capital could be raised to develop one or two competitive production centers, the marginal addition to the welfare of a ghetto the size of Detroit's, Chicago's, New York's, Los Angeles', or even Cleveland's would be insignificant in terms of producing a catalyst for fullscale economic development.

The result, inevitably, of black entrepreneur capitalism is not the creation of an inner city economic infrastructure, but the development of a larger black bourgeoisie, which given rising income, will quickly emigrate from the ghetto taking along both a large part of the wage bill and all of the profit. The tendency toward a black class society is thereby reinforced, with continued low wages and welfare programs in the inner city and a richer, only slightly more numerous, black middle class community on the outside. Again income will flow outward in great quantity, leaving the bulk of the ghetto residents no better off, save for a few more low-wage jobs and a few more black faces across the drugstore counter. Profits are reaped by an enlarged black middle class, while the losses continue to be borne by the poor.

An Alternative...

Even if blessed with normal profits, black privately owned enterprise will fail in the relevant future to aggregate the capital necessary for the creation of a viable inner city economy. Because of the large capital input necessary to initiate a community-wide enterprise, the tendency under black private ownership will be to buy up over time scattered small-scale enterprises rather than accumulate the necessary capital for large-scale high profit investment. In this way independent private black capitalism is doomed to corner store capitalism; inefficient, non-competitive, low-wage, and low profit. There is slim chance that such a beginning can produce the savings for reinvestment and development.

The alternative to both white dominated ghetto intervention and small-scale private black capitalism is communityowned enterprise. Inner city residents can pool both the capital they own and that which can be bribed from the government or other sources on a "no-strings" basis, and under 
democratic rule, invest in cooperative industry on a relatively large scale. Supermarkets, department stores, banks, and intermediate-size factories can then be the first order of business -- not corner drugstores. Creating business centers which are relatively crime-proof compared to sidewalk shops, taking full advantage of scale economies, and aggregating profits will ensure lower costs and larger reinvestment potential. As the black community "owns" the industry, the wages and dividends from such enterprise remain within the inner city. Those who choose to leave the ghet to should not be allowed to take more capital out of the community than the small amount they originally contributed (with some interest) nor should they be permitted to take part of the wage bill with them. As long as there remains unemployment in the inner city, residents who choose to emigrate must relinquish the jobs they hold in community enterprise. Escape from the ghetto remains open, but not at the expense of the majority of the ghet to community. In order to maximize reinvestment so as to build as viable and diversified an inner city economy as possible, leakages of capital and income must be kept to a minimum. Community ownership and control ensures that the route from poverty is provided the entire black underclass, not merely a chosen few. Furthermore, if a good part of black community development is to be financed by federal funds -through low-interest loans or seed grants -- justice is only done if the whole community benefits and not merely a relatively small number of private entrepreneurs. Both on efficiency and equity grounds, then, black cooperative enterprise is preferable to "traditional" corner store capitalism.

\section{And A Realistic Perspective}

Here we must add a word of caution. Despite grandiose plans and even federal support, the black community should not be hoodwinked by either the corporate establishment nor many of its own ebullient leaders into believing that "black capitalism" in any of its forms including black "socialism" can automatically lead to economic and political freedom. For no matter how important a goal, black economic selfdetermination will ultimately be largely an illusion. To be sure, hundreds, possibly even thousands of jobs will be created and many businesses may end up under black control; but in the final analysis, the market will determine which businesses succeed and which fail. Unlike the textbook model, the American market, manipulated in good part by the already existing corporate structure, allows few new small independent enterprises to reach the strata of "big business." The inner city, starved for capital and expertise -- even with federal aid -- begins far back in the field of potential money-winners. Thus 
mythologizing about the possibility of the black community creating through its own industry the route to equal affluence will be in vain or worse, a practice conducive to selfdestructive frustration. In the context that the goal of economic development is the answer per se, the trap of "black capitalism" is laid.

Yet there exists another context in which to place black economic self-determination, and it is in this context that we find the genius of the black economic development strategy. While the creation of a black economy in the ghetto may not lead inexorably to a viable economic base -- competitive with the staunchest of "white" enterprise -- the act of striving toward an inner city economy yields a powerful tool for organizing the black community into a coherent political force capable of extracting concessions on jobs, housing, income, and dignity from the government and from the corporate establishment. While "black socialism" alone may not be capable of rooting out poverty, it may root out powerlessness and thus gain for the black community the indirect means to freedom from poverty and the manifestations of racism. In the striving for economic independence, not only is dependence on the white power structure for jobs and poverty incomes reduced, but the economic incentive to coalesce within the black community increases as well. Jobs and income are created within the community and it is from such a base that political and social power are born.

Black community enterprise will, in addition, have a considerable impact on the whole economy, not because it can successfully compete with white enterprise directly, but because income generated from community enterprise can be used to develop well-financed political organization, capable of confronting City Hall and Congress with a united front. If in the past, the black movement has been stifled by a lack of financial support, especially once it diverged from the strict integrationist political line, the community movement will now have a self-financed base. For while a large part of the "profit" from black community en terprise can be reinvested in expanded business projects, a part can also be earmarked specifically for political activity.

Taken in this context, black community enterprise not only places black faces behind drugstore counters, and allows a moderate scale production sector, but more importantly, it facilitates the creation of an indigenously financed, strictly independent, political force within the ghetto. Unlike "corner store" black capitalism which fails on two accounts: (1) to create an economic infrastructure capable of pulling the black community out of poverty, and (2) to create a meaningful community controlled power base; and unlike corporate 
intervention in the ghetto which adds longevity to white economic and political dominance over the black community, black community enterprise, or what we have called "black socialism" promises a new hope for political and social liberation.

While as a "goal," the black economic development strategy may be an utter failure in any of its forms, as a "means" one of its forms, "black socialism," may be judged in the future an unqualified success. The real question of black enterprise then must not be whether it succeeds on the accountant's balance sheet, but whether it succeeds ultimately in the struggle to redistribute a just share of political and social power toward the black community.

\section{Footnotes}

${ }^{1}$ Sar Levitan, "Community Self-Determination and Entrepreneurship: Their Promises and Limitations," Poverty and Human Resources Abstracts, Vol. 4, No. 1, January-February, 1969 , p. 18 .

2 David Caplovitz, The Poor Pay More, The Free Press of Glencoe, New York, 1963.

$3_{\text {This is not to deny the psychological and cultural }}$ advantages which accrue to the black community from gaining control over its own environment.

${ }^{4}$ William E. Zisch, "The Private Sector's Role in the Urban Crisis," Industrial Relations Center, California Institute of Technology, Pasadena, California, 1968, pp. $10-11$.

5U.S. News and World Report, "'Black Capitalism' at Work: What's Happening in Philadelphia -- An Exclusive Interview," February 17, 1969, p. 63.

6 Ibid.

7 Ibid.

8 Information on the Inner City Business Improvement Forum (ICBIF) was obtained from an oral interview with the organization's Executive Secretary, Walter McMurtry.

${ }^{9}$ Community Self-Determination Bill of 1968, S. 3875, S. 3876, H.R. 18976, H.R. 18460, U.S. Congress. 
${ }^{10}$ At a small graduate seminar in Manpower Economics held at the University of Michigan in October, 1968, Arjay Miller explained that the problem of poverty was basically a technological one. He felt the will for waging war on poverty had been mustered, and only the technical know-how of business economics was necessary now to liberate the impoverished.

${ }^{11}$ Barry Bluestone, "Lower-Wage Workers and Marginal Industries," in Ferman, Kornbluh, and Haber, Poverty in America, second edition, University of Michigan Press, Ann Arbor, 1968.

${ }^{12}$ George Delehanty and Robert Evans, Jr., "Low-Wage Employment: An Inventory and an Assessment," Northwestern University, mimeo, no date. 